\title{
Youth Unemployment Saga In Nigeria: Implications For Security Challenges And Economic Development
}

\author{
Mofoluwawo, E. 0. \\ Department Of Social Studies \\ Emmanuel Alayande College Of Education P .M.B 1010, Oyo.
}

\begin{abstract}
The paper examined the challenge of youth unemployment in Nigeria and its implications for security and economic development. The paper adopted descriptive survey method. A total of 200 subjects were drawn through random sampling techniques across public servants, students and youths in Ogbomoso township of Oyo State, Nigeria. The research questions were analyzed with the use of mean score and standard deviation. The result of the study among others revealed that lack of power supply, lack of practical entrepreneurial skills and mass production of graduates from secondary and tertiary institutions are the causes of unemployment. The implication of these has led to increased social vices, rise in religious riots and militancy, vandalism and destruction of lives, slow pace of economic development and high waste of human resources. Thus, it was recommended that crops and livestock farming should be made attractive through the provision of incentives to young graduates who may wish to go into crop and livestock farming. Entrepreneurship should be drafted into Nigeria's school curricular and made compulsory for all levels in secondary and tertiary institutions of learning. This will infuse the spirit of enterprise, perseverance and merit into the youths as opposed to the quick-quick and now-now syndrome that has overtaken the nation.
\end{abstract}

\section{INTRODUCTION}

Nigeria like many other nations of the world is grappling with her own millennium bulge. Social tension, unemployment-triggered poverty and corruption-induced social inequality have continued to threaten the corporate survival of Nigeria as a country. Nigeria, a nation abundantly endowed with huge natural resources has continued to parade a citizenry that is ranked among the poorest (Oguntuase, 2012). How then can Nigeria's army of jobless and restless youths be transformed into a productive industrial people? A veritable means of tackling Nigeria's present security challenges lie in job creation and expansion of opportunities for entrepreneurial wealth creation (Oguntuase, 2012).

Adelowo, (2012) states that Nigeria no doubt is experiencing a lot of unstable situations, instabilities of all sorts in the areas of economy, politics, education, behavioural patterns, cultural setting, religion and the likes. Such instabilities are seen to be waging serious wars against the peace, progress and development in Nigeria. Coupled with the above is the increasing wave of unemployment among her youths with its attendant effects on economic development of the country.

Corroborating the prevalence of youth unemployment in Nigeria and successive government's inability to curb it, Mofoluwawo and Oladiti (2011) enthused that to provide employment for the teaming population of graduating youths at all levels of education, non-governmental organizations should complement government efforts. It must be noted that the rather limited access has to employment on the part of youths has led to youth restiveness in the country (Briggs, 2008). Every year, thousands of graduates are turned out for whom there are no jobs. Nigerian streets are littered with youth hawkers who ordinarily would have found gainful 
employment in some enterprises or would have demonstrated their skills and resourcefulness if there is an enabling environment and reliable management structures on ground. Instead, the youths have now shifted their attention to cybercrime popularly known as ' 419 '. This is wrong use of technological skill, which ordinarily should have been channeled towards technological advancement as witnessed in the U.S.A, Canada, United Kingdom and China - the emerging world's production and economic power. The large numbers of youth who are unemployed are capable of undermining economic development as they constitute a serious threat if engaged by the political class for clandestine activities (Adepegba, 2011). The reason being that 'security', which is the precondition for any meaningful socio-economic activity has not been fully understood and integrated in the scheme of things. Suffice it to say that youth unemployment in Nigeria is not limited to graduate unemployment only but also to the youth who have little or no formal education.

\section{CONCEPTUALIZATION}

Youth connotes persons who may be male or female whose age range between 15 and 35 years $\mathrm{Au}, 2007)$. This category represents the most active, volatile and yet the most vulnerable segment of the population. Youths are the conglomerate with different background. Though willing and able to work but may not find any or cannot find the type of job that they are trained to do. The youth can also be referred to as the younger generation in any society that are in the period of adolescence and ones below the age of 35 years. This means that by age 15 years, one is preparing to transit from secondary education into the society and at age 34 years, one is fully inducted into the society since 30 years is the terminal point for being involved in the NYSC programme (Alimba, 2010). During this period, youths are full of energy, exuberance and curiosity about life and the environment they find themselves. These attributes make them at that stage to be very vulnerable to social ills and vices, because it is a period of self exploration and identification.

Simply put, unemployment describes the condition of people who are without jobs. The International Labour Organisation (ILO, 22) defines the unemployed as members of the economically active population who are without work but available for seeking work including people who have lost their jobs and those who have voluntarily left work.

Youth unemployment can also be described as the conglomerate of youth with diverse background, willing and able to work, but cannot find any or cannot find the type of job that they are trained to do and which they will be proud to do as their area of expertise. When the supply of labour outstrips the demand for labour it causes joblessness and unemployment. Given the lack of sufficient employment opportunities in the formal sector, young people may be forced to engage in casual work and other unorthodox livelihood sources, thus leading to under- employment (Nwokwu, 2013). Governments at all levels should strive to create viable structure which will encourage the youths to think rationally towards job creation rather than job pilferage and almost unending unemployment proliferation which is in vogue in Nigeria.

Youth unemployment is a prevailing phenomenon in Nigeria in the present dispensation as evidences abound across the country in the way and manners by which youths in such categories parade themselves touching all spheres of human endeavours. Youth restiveness is one of the indices of youth unemployment and it is a despicable act being perpetrated by significant portion of Nigerian youth in various communities which are resultant effects of youth unemployment, as well as neglect of youths among others (Ogundare, Jimoh, Oladokun, 2011) Youth unemployment in Nigeria is not limited to graduate unemployment only but also to the youths with little or no western education. 
Security refers to safety, freedom from danger or risk, protection from espionage, infiltration, sabotage, theft and so on (Nwolise, 1988). It refers to making use of throngs of all soldiers of a distinguished nation state through the use of economic, military and political power and the exercise of diplomacy (Gele, 2009). Nweze (2004) defines it as the presentation, protection and guarantee of the safety of life, property, wealth of the citizenry and measures to guard against threat of the national security. Security is an all encompassing condition in which individual citizens lives in freedom, peace and safety, participate fully in the process of governance, enjoy the protection of fundamental rights, have access to resources and basic necessities of life and inhabit an environment which is not detrimental to their health and well being. Similarly job security is an all encompassing condition in which individual citizens of Nigeria lives in an environment where equal job opportunities are provided for all citizens and not exceptionally for the rich and those with the highest connection. It should equally entail a situation whereby one can have access to the type of job he or she is trained to do and which gives individuals job satisfaction.

Human security the world over goes hand in hand with peace. Where able-bodied and young people wander in search of jobs that do not exist, dangers abound as their restless youthful energy ill most likely be channeled towards violence and crime, leading to fragility and conflict which according to the World Bank impede economic development. President Jonathan recognized this when he made employment generation a cardinal point in his presidential campaign speeches in the early 2011(Oguntuase, 2012).

The National Youth Development Policy (2001, p1) asserts that:

Youths are the foundation of a society. Their energies, inventiveness, character and orientation define the pace of development and security of a nation. Through their creative talents and labour of power, a nation makes giant strides in economic development and socio-political attainments. In their dreams and hopes, a nation finds her motivation; on their energies, she builds her vitality and purpose. And because of their dreams and aspirations, the future of a nation is assured.

Since youths are the major determinants of peace and stability of a nation as reiterated by Ozohu Sulaimon, (2006), the above statement thus stressed the role of youths in the peace and security of a nation.

The rate of unemployment in Nigeria according to Aregbesola(2008) is rapidly increasing especially with the disappearance of job in the public services and with the turning out of an estimated 120,000 graduates annually by Nigerian universities and polytechnics. Unemployment in Nigeria according to Oyebade (2003) can be grouped into two categories: first, the older unemployed who lost their jobs through retrenchment, redundancy or bankruptcy; and second, the younger unemployed most of whom have never been employed (Nwokwu, 2013). The statistics showed that Nigeria has a youth population of about 80 million, representing $60 \%$ of the total population of the country. 64 million of them are unemployed while 1.6 million are under-employed. The 1990-2000 data on youth unemployment showed that the largest group of the unemployed is the secondary school graduates (Awogbenle and Iwuamadi, 2010). Worthy of note is the fact that $40 \%$ of the unemployed are among urban youth aged $20-24$ and $31 \%$ of the rate is among those aged 1519. Two-thirds of the urban unemployed are ranged from 15-24 years old. The educated unemployed tended to be young males with few dependants. The above figures are pointing to the fact that unemployment is a critical issue with far reaching implications for security and virility in Nigeria. 
Youth unemployment has turned Nigeria into a potential recruitment ground for terrorist groups such as Boko Haram in addition to other social evils of redundancy. The most common vices among the youth according to Mofoluwawo (2012) are street roaming in search of nonexistent jobs, alms begging particularly in cities and urban areas; prostitution, smoking, drug addiction and immorality; all in a bid to survive. However, Nigeria hopefully can still make a turnaround at this stage and gravitate towards its vision 202020 of taking a prominent position in the comity of nations. The only strategy is to create jobs and also expand wealth creating opportunities by providing favourable investment climate for enterprise growth and development.

According to the Federal Ministry of Youth Development, young people account for the greatest percentage of unemployment in the country and Nigeria needs to create four million jobs annually to tackle the issue of unemployment in the country (Babalobi, 2010). Today, unemployment has made post graduate degree or second degree in the university to seem like first degree because some youth have gone to the extent of getting postgraduate degree but still cannot get a job.

\section{CAUSES OF YOUTH UNEMPLOYMENT IN NIGERIA}

The major causes of unemployment in Nigeria according to Alanana (2003), Awogbenle and Iwuamadu (2010) are as follows:

Rapid Growing Urban Labour Force Arising From Rural-Urban Migration: This is due to pressure resulting from man-land ratio in the rural areas. Coupled with that is the lack of infrastructural facilities in the urban centers and lack of infrastructural facilities which make the rural life unattractive (Adewoye, 2010). Youths move to urban areas with the probability of securing lucrative employment in the industries. Often times, they engaged themselves in all manners of dirty deals in order to raise thousands of naira to secure visas to travel out of Nigeria in search of greener pastures. For instance, in March 2012, it was reported that two Nigerian young men sold their kidneys in exchange for few thousands of dollars in Malaysia (Njokwu, 2013).

Rapid Population Growth is another Cause of Youth Unemployment in Nigeria: The 2006 census revealed Nigeria's population to be 140 million and the projection for future indicate that the population could be over 180 million by the year 2020 with annual growth rate at $3.2 \%$ (National Population Commission \& ICF Marco 2009). This population growth rate has resulted to rapid growth of labour force which is far outstripping the supply of jobs.

Rapid Expansion of the Education Sector Leading to Increased Supply and Decreased Demand of Educated Manpower: Rapid expansion of the education system which led to increase in the supply of educated manpower above the corresponding demand for them has also contributed to the problem of youth unemployment in Nigeria. For instance, with over 97 universities in the country both federal and state and the increasing demand for higher education, there has been the problem of suitable employment for the varieties of graduates who are turned out by these higher institutions every year (Njokwu, 2013).

Lack of employable skills and outdated school curricula is another cause of youth unemployment: The course content of most tertiary institutions in Nigeria's education system lack entrepreneurial contents that would have enabled graduates to become job creators rather than job seekers. Nigerian graduates need to be trained to develop entrepreneurial skills rather than training them to depend absolutely on white collar jobs (Aregbesola, 2008). 
The skills that many job seekers possess do not match the needs and demands of employers in Nigeria. Nigeria has and is still producing an army of unemployable and unemployed youths (Ijaiya 2007). The reason according to Ahimie(1987) is that the problem of unemployment among educated youth in Nigeria stems from too great emphasis on university education at the expense of such areas as technical and vocational education Ojamoruay (2006) further opines that youth unemployment remains a critical problem and source of insecurity in Nigeria.

Coupled with the above is the lack of vibrant manufacturing sector which has the capacity to absorb unemployed youths in Nigeria. There are over 800 collapsed industries in Nigeria and the persistence of power outage continue to harm industries output. With lesser dependence on PHCN over the years, many firms have collapsed under unbearable burden of the rising cost of diesel for powering their generators. Many manufacturing companies according to Olajide, (2011) have closed down and sent thousands of workers to already saturated job markets. Apt examples are Michelin and Dunlop companies that have fled Nigeria to relocate to neighbouring Ghana.

The issue of massive corruption that is perpetuated on daily basis by successive military and civilian administrations is another cause of youth unemployment. Corruption has permeated the entire social structure of Nigeria and has robbed the country of developing a vibrant economic base. For example, corruption diverts financial resources from building roads, hospitals, schools and otherwise investing infrastructure that would serve businesses, attract foreign investment and create jobs for the jobless youths.(US Ambassador to Nigeria in Crossroads 2011). Funds meant for development projects have been misappropriated, diverted or embezzled and stashed away in foreign banks. The collaboration of the political elites, local and foreign contractors in the inflation of contract fees have robbed Nigeria of the chances of using huge amount of money from oil sales in the last 50 years to develop a vibrant economy that would have created jobs for the youths in various sectors of the economy (Nwokwu, 2013)

In realization of the foregoing there are several efforts to address the plight of youth unemployment in Nigeria. Consequently the following research questions are hereby put forward to underscore the implications of youth unemployment in Nigeria and its implications for security and economic development.

\section{Research Questions}

1. What are the causes of youth unemployment in Nigeria?

2. What are the implications of youth unemployment on national security?

3. What are the effects of youth unemployment on economic development?

\section{METHODOLOGY}

The study adopted the descriptive survey research design to seek for the opinions of the people on the causes of youth unemployment and how this problem has affected national security and economic development of Nigerian citizens. A total of two hundred respondents were selected from five local governments within Ogbomoso metropolis through a purposive sampling technique with thirty (30) respondents comprising male and female youths from each of the local government i.e. Ogbomoso North, Ogbomoso South, Oriire, Ogo-Oluwa and Iresaadu Local governments of Oyo state.

The instrument comprised fifteen (15) structural items to elicit responses from the respondents. The instrument was subjected to content and face validity by the experts. The researcher personally administered the questionnaires. Data collected were analyzed using simple percentage, mean and standard deviation statistical methods. 
Moflouwawo, E. O. (2015). Youth Unemployment Saga in Nigeria: Implications for Security challenges and Economic Development. Advances in Social Sciences Research Journal, 2(3) 107-115.

Research Question One: What are the causes of Youth Unemployment in Nigeria?

\begin{tabular}{|c|c|c|c|c|c|c|c|c|}
\hline $\mathrm{S} / \mathrm{N}$ & ITEM & NO & $\begin{array}{l}\text { POSITIVE } \\
\text { RESPONSE }\end{array}$ & $\%$ & $\begin{array}{l}\text { NEGATIVE } \\
\text { RESPONSE }\end{array}$ & $\%$ & MEAN & S TD \\
\hline 1. & Persistence of power outage & 200 & 81 & 40.5 & 119 & 59.5 & 1.595 & .49 \\
\hline 2. & $\begin{array}{l}\text { Folding up of Local and } \\
\text { Industrial Enterprise }\end{array}$ & 200 & 155 & 78 & 45 & 22 & 1.225 & .42 \\
\hline 3. & $\begin{array}{l}\text { Agricultural sector is not } \\
\text { attractive to the young ones }\end{array}$ & 200 & 175 & 88 & 25 & 12 & 1.125 & .33 \\
\hline 4. & $\begin{array}{l}\text { Lack of employable skills and } \\
\text { practical orientation in } \\
\text { educational institutions }\end{array}$ & 200 & 181 & 90.5 & 19 & 9.5 & 1.095 & .29 \\
\hline 5. & $\begin{array}{l}\text { Mass production of graduates } \\
\text { from tertiary institutions }\end{array}$ & 200 & 131 & 65.5 & 69 & 34.5 & 1.345 & .48 \\
\hline
\end{tabular}

From the table 1, it can be deduced that item 4 has the highest number of responses i.e 181 $(90.5 \%)$ with the mean of 1.095 and .29 standard deviation while item one (1) has the lowest number of responses 81 (40.5\%) with mean of 1.595 and .49 standard deviation. This means that all the items above are very significant and are factors responsible for unemployment in Nigeria.

Research Question Two (2): What are the Implications of Youth Unemployment on National Security?

\begin{tabular}{|c|c|c|c|c|c|c|c|c|}
\hline $\mathbf{S} / \mathbf{N}$ & ITEM & NO & $\begin{array}{l}\text { POSITIVE } \\
\text { RESPONSE }\end{array}$ & $\%$ & NIGATIVE & $\%$ & MEAN & STD \\
\hline 1 & Increase in various crime and social vices & 200 & 190 & 95 & 10 & 5.0 & 1.050 & 22 \\
\hline 2 & Rise in religious riots and militancy & 200 & 176 & 88.5 & 24 & 12.0 & 1.120 & 33 \\
\hline 3 & $\begin{array}{l}\text { Insecurity and armed conflicts in many } \\
\text { communities }\end{array}$ & 200 & 191 & 95.5 & 09 & 4.5 & 1.045 & 21 \\
\hline 4 & Incessant communal clashes in some states & 200 & 170 & 85.0 & 30 & 15.0 & 1.150 & 36 \\
\hline 5 & $\begin{array}{l}\text { Vandalism and destruction of lives and } \\
\text { property }\end{array}$ & 200 & 196 & 98.0 & 4 & 2.0 & 1.020 & 14 \\
\hline
\end{tabular}

Table 2 above revealed that item 5 has the highest frequency and percentage i.e 196 (98\%) and mean of 1.020 and standard deviation stands at .14 while item 4 has the lowest frequency and percentage of $170(85 \%)$ with 1.150 mean and .36 standard deviation. This implies that items one to 5 are very significant and are the major effects of unemployment on national security.

Research Question 3: What are the effects of youth unemployment on economic development?

\begin{tabular}{|c|c|c|c|c|c|c|c|c|}
\hline $\mathbf{S} / \mathbf{N}$ & ITEM & NO & $\begin{array}{l}\text { POSITIVE } \\
\text { RESPONSE }\end{array}$ & $\%$ & $\begin{array}{l}\text { NEGATIVE } \\
\text { RESPONSE }\end{array}$ & $\%$ & MEAN & S TD \\
\hline 1. & $\begin{array}{l}\text { Gangsterism and political } \\
\text { unrest }\end{array}$ & 200 & 177 & 88.5 & 23 & 11.5 & 1.115 & .32 \\
\hline 2. & $\begin{array}{l}\text { Slow pace of economic } \\
\text { development }\end{array}$ & 195 & 190 & 97.4 & 5 & 2.6 & 1.026 & .16 \\
\hline 3. & High waste of human resources & 200 & 127 & 63.5 & 73 & 36.5 & 1.365 & .48 \\
\hline 4. & $\begin{array}{l}\text { Kidnapping of foreign investors } \\
\text { in some parts of the country has } \\
\text { a lot of implications for the } \\
\text { economy of Nigeria }\end{array}$ & 200 & 124 & 62 & 76 & 38.5 & 1.605 & .58 \\
\hline 5. & $\begin{array}{l}\text { Prevention of development } \\
\text { partners and investors from } \\
\text { doing business or investment in } \\
\text { Nigeria }\end{array}$ & 195 & 137 & 70.3 & 58 & 29.7 & 1.297 & .46 \\
\hline
\end{tabular}

Table 3 shows that item 2 has the highest positive response and percentage 190(97.4\%) and mean score of 1.26 and .16 standard deviation while item 4 has the lowest frequency and 
percentage of $124(62 \%)$ with mean of 1.605 and .58 standard deviation. This indicates that the items 1-5 are the effects of youth unemployment on economic development in Nigeria. The total number of item five is 195 because five people decided to be neutral in their responses.

\section{DISCUSSION}

This study investigated into youth unemployment in Nigeria and its: implications for security challenges and economic development. The results of the data analysis revealed that persistent power outage which culminated into folding up of local and foreign industrial enterprises, unattractiveness of agricultural sector to the young ones, lack of practical orientation in educational institutions as well as mass production of graduates from tertiary institutions are the major causes of youth unemployment in Nigeria. The findings of the study corroborates that of Nwokwu(2013), Aregbesola(2008), Babalobi(2010), Ijaiya (2007) and Olajide(2011) who believe that causes of youth unemployment in Nigeria range from lack of employable skills and practiced orientation in our tertiary institutions, persistence of epileptic power supply as well as mass turning out of graduates as some of the major causes of youth unemployment in Nigeria.

The findings of the study further showed that increase in various crimes and social vices, rise in religious riot and militancy, incessant communal clashes and vandalism and destruction of property are part of the implications of youth unemployment. The findings is in consonance with the World Bank (1992) and Ogundare, Jimoh and Oladokun(2011) who maintain that youth all over the world in their search for jobs that does not exist often result to restiveness which are likely channeled towards violent crime leading to fragility of the polity and sometimes, conflict among its members.

The results of this study also indicated that slow pace of economic development, high wastes of human resources, kidnapping of foreign investors in some parts of the country and others are the effect of youth unemployment on economic development. These findings support that of National Youth Development Policy of 2001, Adepegba(2011), Nwokwu, (2013) and Ozolu Sulaiman 2006 who submit that "youth are the major determinants of peace and stability of a nation and that the large number of youth who are unemployed are capable of undermining economic development as they constitute a serious threat if engaged by the political class for clandestine activities".

\section{CONCLUSION}

It is an established fact that all human societies have to deal with one challenges or the other. The issue of youth unemployment in Nigeria is a core value that deserves primary attention. The government needs to put in several efforts to address the plight of youth unemployment in Nigeria by engaging youths in some skills or other things that could free them from poverty, hunger, diseases and social injustice. It is the deficiency of these values among the generality of Nigerians that has provoked recourse to crime and violence

\section{RECOMMENDATIONS}

Based on the findings of this study the following recommendations are made:

- Entrepreneurship education should be provided among the youth. Skills acquisition programmes which could empower graduates and non-graduates alike should be developed by the government. Functional youth centres and programmes that would enable them acquire sellable skills and thereby making them productive should be encouraged. This will in turn reduce violence and crime. 
- Integrated rural development and re-orientation programmes of economic activities and social investments towards the rural areas should be embarked upon by Nigerian government so as to create an appropriate rural-urban balance.

- Capital projects should be made available by the various tiers of government. This will make adequate infrastructure available for productive enterprises and employ more people.

- Government should also support youth in agriculture. This can be done by providing loans, land, seeds and modern equipment that will make them become attractive to agriculture as a means of livelihood.

\section{References}

Adelowo, E.D. (2010). Religious Harmony and Peaceful Coexistence in Relation to Sustainable Development. National Association for the Study of Religions and Education (NASRED)

Adepegba, A (2011). Police Arrest 51, Post Election Violence: The Punch, Saturday, 23 April. P6

Adewoye, W.0 2010. "Youth Unemployment" Retrieved from http://www.thefuturenigeria.com/on June 25, 2013

Alanana, 0.0 (2003). Youth Unemployment in Nigeria: Some Implications for the The Third Millennium, Global Journal of Social Sciences 2(1) 21-26

Animie, F.A.(1987). “The Roots of Educated Youth Unemployment in Nigeria” In Journal of Economics vol 23 pp 195-196 Spring.

Awogbenle, A.C and Iwuamadi. K.C 2010. Youth Unemployment: Entrepreneurship and Development Programmes, 4(6) 831-835

Aregbesola, B.2008. “Unemployment in Nigeria: On The Increase” In Nigerians In America Dec 14, 2008. Retrieved from http://www.nigeriansinamerica.com/ on May 20, 2013

$\mathrm{AU}, 2007$. Report of the 1st Extra Ordinary Meeting of the Bureau of the Conference of the Africa Union Youth Character held in Tripoli, Libya, October

Babalobi, A. (2010). "Youth Unemployment in Nigeria" in the Nigerian News: June 25, 2010. Retrieved from http://assemblyonline.info on June 4, 2013.

Briggs,C. 2008. Empowering Youths for Sustainable Development Management in Nigeria 44(1) January.

Federal Government of Nigeria (2001). National Youth Policy. Available at http://www.thepresidency.gov.2a/docs/policy/nationalyouthpolicy.pdf-retrieved 2013.

Gele, S.A.M. (2009) National Security in Nigeria. A paper presented at the 25th Annual National Conference of Social Studies Association of Nigeria (SOSAN)

Ibrahim, F.O (2008) Ethno-Religious Conflicts in Kano State; Poverty as a Major Explanatory Factor in Mustapha, C, Duze, etal (eds) Poverty in Nigeria, Cause, Manifestations and Alleviation Strategies, London; Adoms and Abbey Publishers.

Ijaiya, B.S.(2007)"Addressing Youth Unemployment through Entrepreneurship Education" in the Ilorin Journal of Education, vol 27 August 2007 pp54-60

International Labour Organization (ILO) Resolution Concerning Statistics of the Economically Active Population, Employment, Unemployment and Underemployment Adopted by the Thirteenth International Conference of Labour Statisticians (October 1982, P.4.

Manuaka, T.2011. 'An Eye on Youth Development' Business Journal July 11p.31

Mofoluwawo, E.O (2012) Developing Nigerian Youth Through Social Studies Education Implications for National Development. In V.O Edo and E.F.K Salami (Eds.) Issues and Trends in Nigerians Development pp. 345-354.

Nweze, A.(2004) "Internal Security Threats in Nigeria" in Briggs and Sanda 2004. Pp 1169-90.

Njokwu, M. (2013). The Effects of Youth Unemployment and Its Implication on Socio-Economic Stability of Nigerian Democracy.

Nwolise, O.B.C (1988). Nigeria, the First 25 Years. Ibadan.Heineman Publishers 
Ogundare, I.O; Jimoh, J.B and Oladokun, T.A(2011) Economic Meltdown and Youth Restiveness in Nigerian in Ismaila, B.R. and Ojebode, P.A. (Eds.) The Nigeria Nation and Management of Conflicts and Crises p. 376

Oguntuase, 0 2012. National Security Challenges: The Panacea in Youth Empowerment In The Gaurdian Tuesday, October 30 pg45

Ojameruay, E (2006, "Sports Promotion as an Instrument for Productive Youth Engagement: A case study of IFESH Calm Project" A Press Release by the Nigerian International Athletes Association October 2006.

Olajide, T. (2011) “Unending Power Plague” in the News, June 13, 2011. Retrieved from http://thenewwestafrica.com on May 25, 2013

Ozohu-Sulaiman, A. (2006). The Nigerian Youth in Contemporary Political Development Relevance, Challenges, and role expectation. The Constitution A journal of Constitution Development 6 (4); 97-11 Population Reference Bureau (2006), The World's Youth 2006 data sheet Available:http://www.prob.org/pdf06/World's Youth 2006 Data Sheet.pdf.retrieved 2013

Torrence, P.Mc Caulley (2011)Corruption Diverts Financial Resources. Crossroads December 2011, vol 17 P.7

World Bank (1992). Youth, Conflict, Security and Development, Available: http://www.realityfald.org/roadreport, php?table=roa2006 id=6-retrievesd 2013. 